\title{
OLGU SUNUMLARI
}

\section{A CASE OF HILAR \\ CHOLANGIOCARCINOMA WITH 5.5 YEARS SURVIVAL AFTER HEPATECTOMY}

\author{
HEPATEKTOMIYYLE 5.5 YIL YAŞAYAN \\ BIR HILLER KOLANJIOKARSINOM OLGUSU
}

\section{SUMMARY}

\author{
Kimitaka KOGURE \\ Yasushi TSUZUKI \\ Tatsuo SHIMURA \\ Nobuyuki AOKI \\ Masatoshi ISHIZAKI \\ Masaaki NEMOTO
}

A 68 year old man with hilar cholangiocarcinoma had undergone alleft hepatic lobectomy and hilar bile duct resection with hepaticojejunostomy. The right hepatic duct and the common bile duct were macroscopically excised at $1 \mathrm{~cm}$ and $2 \mathrm{~cm}$ distal from the margin of the cancer; respectively, however, cancer invasion was histologically positive at the stump of the right hepatic duct.The first and second group of lymph nodes were dissected. Metastasis was detected in all dissected lymph nodes.

After the operation the patient could live with a good quality of life for five years. There after the patient had fever and abdominal pain and retrograde cholangitis was suspected. Six months later, the patient ultimately died of renal failure due to cancer invasion of both side of the ureters, however, there was no sign of the obstructive jaundice.

(Key words: Bile duct carcinoma, Extrahepatic bile duct, Liver resection)

\section{ÖZET}

68 yaşındaki sarıklı bir erkek hastada hiler bölgeye yerleşmiş safra yolu kanseri saptandı. Sol hepatik Lobektomi ve tümör ekstirpasyonu uyguland. Ekstirpasyon tümörün $1 \mathrm{~cm}$ proksimal ve $2 \mathrm{~cm}$ distalinden yapılmasına rağmen sağ hepatik kanal güdüğ̈ histolojik olarak pozitif idi. Diseke edilen tüm lenf nodülleri metastaz içeriyordu. Radyoterapi ve kemoterapi uygulanmad. Ameliyattan sonra hasta 5 yıl konforlu bir yaşam sürdü. Ateş ve karın ağrısı yakınmaları ile tekrar müracaat eden hastada retrograd kolanjit düşünüldü. Her iki ureterin metastazlarla tıkanması sonucu 6 ay sonra kaybedildi. hastada ölünceye kadar sarılık gelişmedi.

(Anahtar Sözcükler: Diş safra yolu, Karaciğer rezeksiyonu, Safrayolu kanseri)

Department of Surgery, Gunma University,

(K. Kogure, T. Shimura, N. Aoki, M.Ishizaki, M. Nemoto)

School of Medicine 3-39-15 Showamachi Maebashi

371 JAPAN

Tone Central Hospital.(Y. Tsuzuki) 1855-1 Higashiharashinnmachi Numata

City 378 JAPAN

Reprint from: K. Kogure 
The prognosis of hilar cholangiocarcinoma is unfavourable, although developments in diagnostic procedures and improvement in the surgical technique(2). We report a rare case of hilar cholangiocarcinoma who survived five years six months though cancer cells rested at the surgical margin of the right hepatic duct and lymp node metastasis and perineural invasion were positive.

\section{CASE REPORT}

A 68 years old man was admitted with general fatigue, itching and slight jaundice. Physical examination revealed slight jaundice of the skin and conjunctiva, but no mass in the abdomen. Serum chemistry showed a bilirubin of $5.4 \mathrm{mg} / \mathrm{dl}$, S-GOT 51 IU/1, S-GPT $48 \mathrm{IU} / 1$ and serological tests for hepatitis viruses revealed HBS-Ag (-), HBS-Ab (-) and HA-Ab (-). CEA, AFP and CA 19-9 were all within normal range.

Ultrasonographic examination and computed tomography revealed dilatation of the intrahepatic bile ducts, but showed no remarkable lymph node enlargement around the hepatoduodenal ligament and $a b-$ dominal aorta.

Endoscopic retrogade cholangiopancreaticography (ERCP) and percutaneous trans-

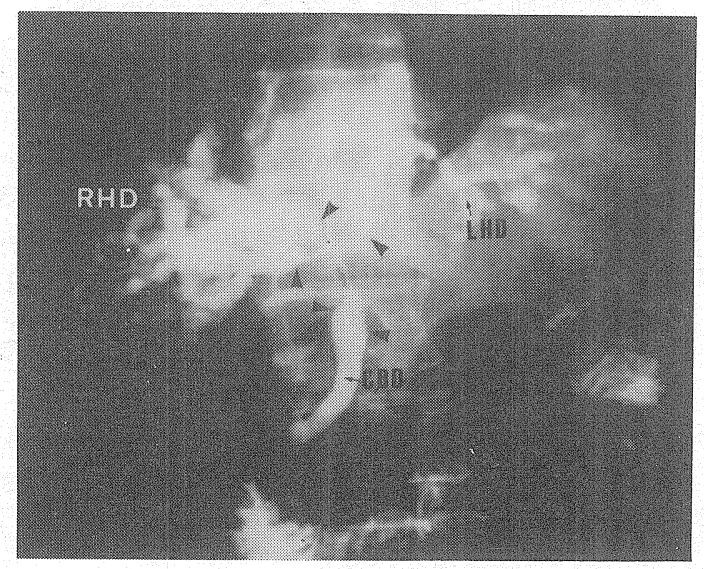

Fig. 1: PTC revealed the obstruction of hepatic hilus with cancer. Allows $(\triangle)$ indicate the extension of cancer.

RHD: right hepatic duct, LHD: Left hepatic duct, CBD: common bile duct hepatic cholangiography (PTC) revealed obstruction of the bile duct at the hepatic hilum (Fig. 1).

The bile duct was drained by the catheter which was left in-situ during the PTC examination for two weeks before operation. The serum bilirubin levels decreased from $5.4 \mathrm{mg} / \mathrm{dl}$ to $1 \mathrm{mg} / \mathrm{dl}$.

Arteriography was performed to assess the resectability and it revealed no involvement of the hepatic artery and the portal vein.

The patient underwent a left hepatic lobectomy with an end to side right biliary enteric anastomosis on a Roux-en-Y loop. The tumor included the cystic duct and extended into both the right and left hepatic ducts. The right hepatic duct as macroscopically resected at $1 \mathrm{~cm}$ from the margin of the cancer and the jejunal loop was anastomosed with each five right hepatic ducts, respectively (Fig. 2 a, b). All lymph nodes in the hepatoduodenal ligament, around the celiac axis, and at the liver hilum were removed.

The early postoperative course was uneventful except a slight episode of the retrogade cholangitis. Postoperative hepatobiliary scintigraphy with $\mathrm{Tc} 99 \mathrm{~m}$ revealed good bile excretion and drainage into the jejunal loop (Fig. 3). The patient's body weight

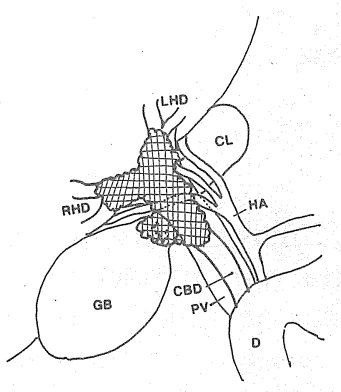

A

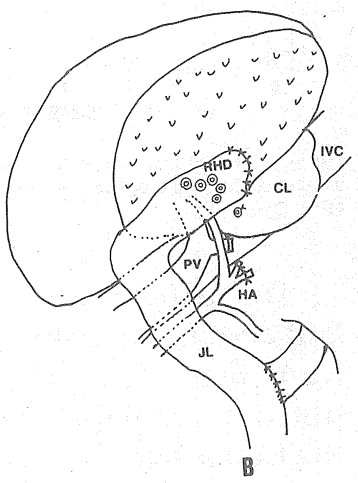

Fig. 2: The sketch of the ehtension of the cancer (A) and the operative procedures. The jejunal loop was anastomosed with the five right hepatic ducts, respectively (B).

$\mathrm{CL}$ : caudate lobe, GB: gallbladder, PV: portal vein, HA: hepatic artery, D: duodenum, IVC: inferior vena cava, JL: jejunal loop artery, D: duodenum, IVC: inferior vena cava, JL: jejunal loop. 


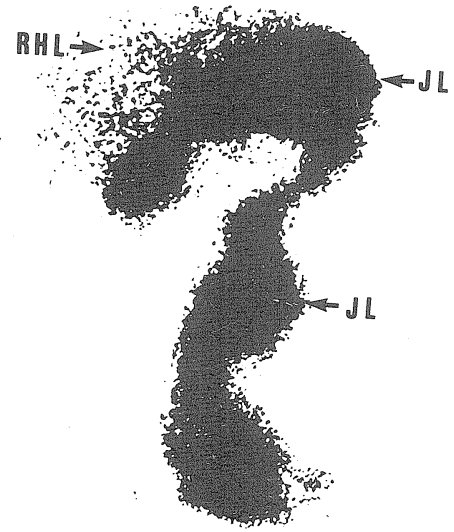

Fig. 3: The hepatobiliary scintigrahp with $\mathrm{TC}^{99} \mathrm{~m}$. Tc ${ }^{99} \mathrm{~m}$. was sufficient. ly excreted into the jejunal loop from liver.

RHL: right hepatic lobe, JL: jejunal loop.

increased from $49 \mathrm{~kg}$ to $75 \mathrm{~kg}$ during three years (Fig. 4). Three years six months after the operation a slight decrease in body weight was observed and it was followed by a slight increase in plasma CEA and CA-199 levels.

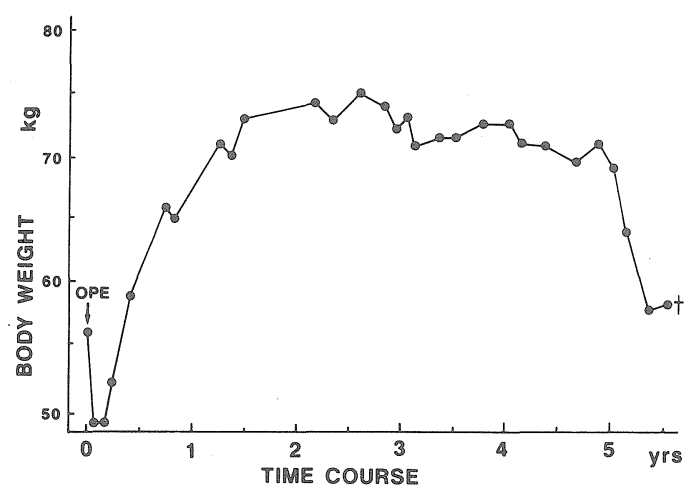

Fig. 4: The changes in the body weight after the operation. The body weight extreamly increased from $49 \mathrm{~kg}$ to $75 \mathrm{~kg}$
OPE: Operation.

The patient was readmitted with fever and abdominal pain of the right hypochondrium five years after the operation. Computed tomography revealed recurrence of the tumor over the retroperitoneal cavity. Bilateral ureter involvement and obstruction with the infiltrating cancer was detected. The body weight of the patient progressively decreased before death whereas the tumor marker, CA19-9 sharply increased from $20 \mathrm{mg} / \mathrm{ml}$ to $4.440 \mathrm{mg} / \mathrm{ml}$.
The patient died of renal failure after five years six months but no jaundice had been noticed during the post operative course.

No chemotheraphy and no irradiation was performed to the patient during the entire course of the disease.

\section{Pathology}

Grossly, the hilar bile duct was obstructed by the tumor which showed nodular shape and it extended to the right and left hepatic ducts and the distal extension of the tumor included the cystic duct. Histologically, the cancer was made up of irregular tubular structures in the connective tissue stroma (Fig. 5) and it extended to the

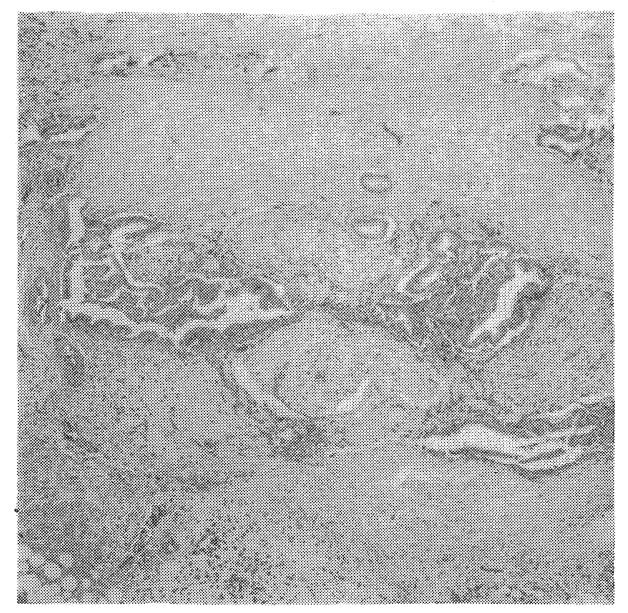

Fig. 5: The microscopic findings. The cancer was made up of the irregular tubular structures in the connective tissue stroma.

stumps of the right hepatic ducts and common bile duct, so that the surgical margins were positive for cancer cells. The tumor also infiltrated into the perineural space but not into the vascular space of the connective tissue around bile ducts. Metastases were found in the lymph nodes around the common hepatic artery belonging to the second group. Also, direct invasion into the hepatic parenchyma was found.

\section{DISCUSSION}

Hilar cholangiocarcinoma is generally defined as a bile duct cancer which simulta- 
neously locates at the right and the left hepatic duct and common bile duct (3). Bismuth (4) divided hilar cholangiocarcinoma into four types according the location of cancer and Bengmark (3) subdivided his classification. As the cancer in our case mainly extends into the right hepatic duct it belongs to the IIIa type of Bengmark's classification. The initial symptom of hilar cholangiocarcinoma is commonly jaundice and ERCP and PTC are available in the diagnosis of these cases. The reduction of the jaundice by percutaneous transhepatic bile duct drainage (PTBD) enables a major radical operation including hepatic resection and pancreatoduodenectomy feasabile $(1,3)$. Since biliary tumors are a tendency for direct invasion of the hepatic parenchyma and of the bile duct draining the caudate lobe, extended right or left hepatectomy with simultaneous resection or the caudate lobe have been performed in some cases $(5,6,7)$. However, the prognosis of hilar cholangiocarcinoma is unfavourable despite progresses the diagnostic procedures and improvement in the surgical technique $(1,3,4)$. Only a few cases of five year survival have been reported including $3 / 37$ (8\%) by Nakayama (3), 3/31 (9\%) by Odaka (9), 1/35 (3\%) Hachisuka (10), 3/28 (11\%) by Okamura (11), 1/26 (4\%) by Kawaharada (5), 2/21 (9\%) by Harada (12), 4/24 (16\%) by Tsuzuki (13), $9 / 57$ (16\%) by Todoroki (1), 3/22 (13\%) by Bengmark (3), $4 / 24$ (21\%) by Nimura (7) and 2/54 (4\%) by Langer (2). The prognosis of hilar cholangiocarcinoma is affected by a number of factors such as the histological pattern, the invasion of extra ductal tissue, lymph node metastasis and the existence of the cancer at the surgical margin $(8,14)$. Many reports indicate that papillary or polypoid shape of carcer have good prognosis $(8,15,16)$. Nakayama (8), Koyama (14) and Todoroki (1) reported that only papillary shape of carcinoma could survive over five years after surgery. They also reported that patients with microscopically, papillary or papillotubular pattern have a better survival than those with other his- tological patterns $(1,3,14)$. Ouchi (17) indicated that histological appearance of carcinoma may be valid as a fundamental factor to determine the mode of spread of the carcinoma of the upper bile duct and prognosis of the patients. In our case the gross shape of cancer is nodular infiltrating type with histologically tubular pattern. However, there has been not reported five year survival in which nodular infiltrating type of cancer was observed previously.

The surgical margin of the bile duct is an important factor that affects the prognosis (14). However, complete resection of a cancer of the hepatic duct is considerably difficult. The ratio of the cancer positive cases at the surgical margin of bile ducts were 33 $\%(5 / 15)$ by Tsuzuki (13), $31 \%(4 / 13)$ by Kawaharada (5), $38 \%$ (14/37) by Nakayama (8), $69 \%(18 / 26)$ by Nakamura (18), $32 \%$ $(12 / 37)$ by Odaka (9) and $56 \%(5 / 9)$ by Harada (12). Our case survived five years six months though the cancer cells were found at the surgical margin of the right hepatic duct. Todoroki (1) reported three simi-lar cases who survived over five years without recurrence though the cancer cells at the surgical margin were positive.

Since hilar cholangiocarcinoma is apt to involve the perineural space or to invade perivascular space or to invade perivascular space of the periductal tissues the dissection of the sorrounding tissues is important (3). The rate of cancer invasion into the periductal tissue is $32 \%(12 / 37)$ by Odaka (9), $56 \%(5 / 9)$ by Harada (12) and $73 \%(27 / 37)$ by Nakayama (8). Nakayama reported that there was no five year survival in cases with lymph node metastasis, whereasTodoroki (1) reported three cases who survived over five years even though they had definite lymph node metastasis. Our case also could live with a good quality of life during the five years after operation in spite of the cancer positive surgical margin, the perineural invasion and the lymphnode metastasis.

Bengmark (3) reported a case who survived 14.3 years, who died of recurrence of the tumor. Todoroki (1) indicates that there is a slow growing type in cholangiocarcio- 
noma and the importance to examine for recurrence even when the patients have lived over five years.

\section{ACKNOWLEDGEMENT}

We would like to thank Prof. Dr. Ali Mentes, for his contributing on the manuscript.

\section{REFFERENCE}

1. Todoroki $T$, Kawamoto $T$, Koike N, et al. Clinicopathological Study On The Long Tern Survizors Following Resection of Hilar Bile Duct Cancer. Jap I Gastroenterol Surg. $1991 ; 24$ (6); 1341-50.

2. Langer I.C, Langer B, Tayler B.R, et al. Carcinoma Of The Extrahepatic Bile Duct; Results Of An Aggressive Surgical Approach. Surgery 1985; 98 (4); $752-9$.

3. Bengmark S, Ekberg H. Eviander A, et al. Major Liver Resection For Hilar Cholangiocar-cinoma. Ann Surg. 1988; 207 (2): 120-5.

4. Bismuth H, Corlette M.B. Intrahepatic Cholangioenteric Anastomosis In Carcinoma Of The Hilus Of The Liver. Surg Gynecol Obstet. 1975; 140): $170-8$.

5. Kawaharada Y, Suzuki H. Surgical Treatment Of Hilar Carcinoma Of The Bile Duct, With Special Referrence To Anatoniy of The Hepatic Hilum and Caudate Lobe. Jap J Gastroenterol Surg. 1984; 17 (9): 1684-8.

6. Mizumoto R, Kawaharada Y, Suzuki H. Surgical Treatment of Hilar Carcinonia of The Bile Duct. Surg Grynecol Obstet. 1986; 162:-153-8.

7. Nimura Y. Hepatic Resection For Carcinonn Of The Hepatic Hilus. Joumal of Clinical Surgery (Jap). 1989; 44 (3): 311-21.

8. Nakayama T, Fukuda Y, Toru T, et al. Studies on surgical treatment for resection of the carcinoma at the junction of the main hepatic duct. Jap J Gastroenterol Surg. 1984; 17(9): 1689-93.
9. Odaka $M, R y u M$, Usui S, et al. Surgical treatment of carcinoma of the hilar hepatic ducts. Jap I Gastroenterol Surg 1984; 17 (9): 1698-1702.

10. Hachisuka K, Yamaguchi A, Kondo oS, et al. rrdiation therapy with Cobalt-60 beam as an adjurant to Surgery for carcinomi of the bile duct at the liver hilus. Jap I Gastroenterol Surg. 1984; 17 (9): 1717 20.

11. Okamura T, lwasaki Y. Clinicopathological aspects of carcinoma of the hepatic huilus. An analysis of severe cases survizing over 2 years after Surgery. Jap I Gastroenterol Surg. 1984; 17(9): 1712-6.

12. Harada N, Tsuchiya R, Tsunoda T, et al. Surgical aspects of carcinoma of the hepatic hilus. Jap I Gastroenterol Surg. 1984; 17(9): 1709-7.

13. Tsuzuki S, Ueda M, Takahashi S, et al: Surgical treatment for carcinoma of the junction of the hepatic duct. Joumal of Clinical Surgery (Jap) 1989; 44(3): 323-9.

14. Koyama K, Goto H, Sato T, et al. Operatize results and prognostic fastors of the upper bile duct cancer. Jap I Gastroenterol Surg 1984; 17(9): 1709-11.

15.Todoroki T, Okanura T, Fukada K, et al. Gross appenrence of carcinoma of the nanin hepatic duct and it's prognosis. Surg Gynecol Obstet. 1980;150: 3340.

16. Kozuka S, Tsubone M, Hachisuka K. Ezolution of carcinoma in the extrahepatic bile ducts. Cancer. 1984; 54: 65-72.

17- Oucki K, Suzuki M, Matsuno S, et al. Histological appearence of carcinoma of the upper bile ducts and its node of spread. Japan Surgical Society 1987; 88(7): 845-51.

18. Nakamura $M$, Hanyu F, Imaizumi $T$, et al. Prognosis in the resection of carcinoma at bifurcation of the hepatic ducts. Jap J Gastroenterol Surg. 1984; 17(9): 1694-7. 